\title{
SWOT Analysis on Credit Guarantee Business Sector in Indonesia: A Study from Jamkrindo
}

\author{
Vindaniar Y. Putri, Dhea S. Tasya, and Ajeng Rahayu
}

\begin{abstract}
This study aims to describe the company external and internal environment using SWOT Analysis in credit guarantee sector. We took Perum Jamkrindo as a sample for our research. Perum Jamkrindo is one of the SOE in Indonesia that established under constitution no. 1/2016 on January 19, 2016, concerning guarantee. This research used a qualitative and quantitative approach, with descriptive method. Perum Jamkrindo position is in Progressive Quadrant I with strengthweakness total is 1.377 and threat-opportunity total is 0.649 . This SWOT Analysis also produces an alternative strategy focus, that is the SO Strategy. The implementation of this paper is the company might hold or maintain the product innovation strategies. Also, branch mapping to seek the potential branch, improving serving quality to partners, and integrating IT systems for the effectiveness of the company's business.
\end{abstract}

Index Terms-Credit guarantee, SWOT Analysis, IFAS, EFAS.

\section{INTRODUCTION}

Planning a business strategy for business development is very important for the company. Conducting the company strategy formulation process, company should consider many things. The government regulations and policies, competitive conditions and overall industry attractiveness. Also, market opportunities and external company threats, the strength of company resources, competency, and competitive capabilities [1].

Every type of business must have a different business strategy, including a credit guarantee. Credit guarantee works as third-party credit risk mitigation to lenders through the absorption of a portion of the lender's losses on the loans. This business aims to reduce the financial loss suffered by the institutions, specifically for Small Business Enterprise (SME) in the case of default. Mankiw (1986) believe that the SME might suffer from asymmetric information among borrowers and lenders which cause of negligence. The reduction of information asymmetry is the government's final goal is to provide the desired level of loans to SMEs, by reducing information asymmetry. Currently, more than 170 counties are using the credit guarantee program, such as United Kingdom, Japan, Taiwan,

Manuscript received February 21, 2020; revised May 2, 2020.

Vindaniar Y. Putri is with Finance and Banking Administration Department, Vocational Education Program of Universitas Indonesia, West Java, 16421, Indonesia (e-mail: vindaniar.putri@ui.ac.id).

Dhea S. Tasya is with Faculty of Economic and Business, Universitas Indonesia, Indonesia (e-mail: dheasaummitasya@gmail.com).

Ajeng Rahayu was with Finance and Banking Administration Department, Vocational Education Program of Universitas Indonesia. She is now with a Financial Industry in Indonesia (e-mail: ajeng.rhyu61@gmail.com).
Germany, Malaysia, Thailand, Indonesia, and other advanced countries [2]-[4].

In Indonesia, the credit guarantee sector runs by State Owned Enterprises (SOE), PT Asuransi Kredit Indonesia or Askrindo (Persero) and Public Company (Perum) Guarantee Credit Indonesia (Jamkrindo). The basic principle of the two companies is taking over the risk of guaranteed failure in fulfilling their financial obligations to the recipient of the guarantee, but not eliminating guaranteed financial obligations to the recipient of the guarantee until the recipient. Both companies have products that are more or less similar, even though they are in two different industries. This condition is a threat to both companies because it can make the bank as the recipient of collateral make a high bargaining position.

However, business activities in this field are strongly influenced by government regulations. The Minister of Finance Regulation has issued several regulation for credit guarantee such as PMK Number 20 / PMK.05 / 2010) concerning People's Business Credit, which was published January 28, 2010, concerning the increase in the Guarantor Fees (IJP) from $1.5 \%$ to $3.25 \%$ and only $70 \%$ received by the company $(2.27 \%)$. The inflation caused MSMEs to pay a service fee higher than the IJP tariff raised before. If IJP rates increased, then the ability to guarantee non-performing loans would increase.

Therefore, if the IJP is not growing, the microcredit program (KUR) guarantor company's capital will gradually be eroded. Meanwhile, the Indonesian Ministry of Economic Affairs has set a $7 \%$ p. An interest rate for KUR by the Coordinating Minister for Economic Affairs Regulation Number 11 of 2017, which was valid from January 12018 [5].

The most important tools for facilitating understanding is SWOT analysis [6], [7]. It helps organizations to gain a better insight of their internal and external business environment when making strategic plans and decisions by analyzing and positioning organization's resources and the context in four areas: Strengths, Weaknesses, Opportunities and Threats [8]. Based on the description, the writer tries to use the SWOT Analysis method based on the calculation of the values of the Internal Factors Analysis Summary (IFAS) and External Factors Analysis Summary (EFAS) Matrix.

\section{LITERATURE REVIEW}

SWOT analysis is one of the analytical instruments that has developed since the 1960s [8]. SWOT analysis is the identification of various factors systematically to formulate a company's strategy. This analysis is based on logic to maximize strengths and opportunities (Opportunities), but 
can simultaneously minimize weaknesses (Weakness) and threats (Threats) [9]. "S" and "W" are internal factors, while "O" and "T" are external factors. After identifying the SWOT factors, every organization should use its strategies to protect or improve strengths and eliminate weaknesses, the usage of opportunities and collation with threats [10], [11].

SWOT is used to assess external strengths and weaknesses and challenges faced. All organizations have strengths and weaknesses in the functional area of the business. No company is as strong or weak in all business areas [12], [13]. Thus, the strategic management must analyze the company's critical factors (strengths, weaknesses, opportunities and threats) under newest or current conditions [14], [15].

Internal environment analysis is the process of identifying and evaluating company characteristics such as sources, capabilities and core competencies. The business function approach seeks to identify and assess internal factors that include the company's capabilities, and limitations that usually categorized as Management; Marketing; Finance; Production and Operations; Research and Development [16], [17].

External environment analysis is the process of identifying and evaluating information from outside the company to seek the opportunities and threats faced by the company. External environment analysis aims to create a limited list of opportunities that can benefit the company and various risks that must be avoided. This external environment analysis is intended to identify critical variables which can be implemented as the company's strategic. David (2004) divided the external environment into three types, namely General Environment / Macro Environment, Industrial Environment and Competitor Environment [17].

Internal and external factors then incorporated into a matrix called Internal Factor Analysis Summary (IFAS) and External Factor Analysis Summary (EFAS). The internal and external strategic factors have been incorporated into the quantitative matrix to formulate the company's competitive strategy model. SWOT analysis, types of approaches, SWOT Matrix Qualitative Approach developed by Kearns eight boxes and Quantitative Approach SWOT Analysis developed quantitatively through the SWOT analysis developed by Pearce and Robinson (1997) [18].

\section{Methodology}

This study uses a qualitative approach and a quantitative approach because of the eagerness to describe the business strategy of credit guarantee company using SWOT matrix related to external factors (opportunities and challenges) and internal factors (strengths and weaknesses). As for data processing sourced from financial statements, we need the quantitative approach to test the predetermined hypothesis, namely the increase in guarantee volume is directly proportional to the rise in profits and using the time series method. The results of the study besides will be analyzed descriptively, namely identifying various factors systematically to formulate a strategy.

According to David (2004), the stages of preparing IFAS
(Internal Factors Analysis Summary) Matrix and EFAS (External Factors Analysis Summary) Matrix, as follows:

1) Column 1, determine the external factors that become opportunities and threats and internal factors that become strengths and weaknesses for the company.

2) Column 2, weight each of these factors with a scale ranging from 1.0 (necessary) to 0 (not necessary), according to the effect on the company's strategic position (all of these weights should not exceed the score of 1.0).

3) Column 3 of the IFAS Matrix and the EFAS Matrix, give a rating ranging from 1.0 to 4.0 on each internal factor to show how much influence it has as strengths and weaknesses, where:

Value 1: low, responseless

Value 2: medium, response equals an average

Value 3: high, response above average

Value 4: very high, superior response

4) Column 4, multiply the weight (in column 2) by rating (in column 3).

5) Column 5, add the proportion of the score in column 4 to get the total weighting score for the company.

This total value shows how the organization reacts to external and internal strategy factors.

With the calculation of the formula:

1) Variable formula $X$

$$
\begin{gathered}
X=\text { Total Strength }- \text { Total Weakness } \\
X=S-W
\end{gathered}
$$

2) Variable formula $Y$

$$
\begin{gathered}
Y=\text { Total Opportunities }- \text { Total Thread } \\
Y=O-T
\end{gathered}
$$

SWOT analysis has two types of approaches as follows: [18]

\section{1) SWOT Matrix Qualitative Approach}

The SWOT matrix qualitative approach includes the two boxes that are external factors, while the remaining two boxes are internal factors (strength and gratitude). The other four squares of strategic issues that arise as a result of a common point between internal and external factors.

2) SWOT Matrix Quantitative Approach

The calculation is conducted through three stages:

a) Perform calculation of score (a) and weight (b) point factor set a total value of multiplication score and weight $(c=a x b)$ on each SWOT factor. The scores (a) of each factor point are calculated independently (other factor points should not assess the assessment of a factor point). The selected scale range determines the accuracy of the evaluation, but 1-10 is commonly used, assuming that the value of 1 is the lowest score and 10 denotes a highly competitive score. The weight (b) of each factor point is calculated interdependently. That is, one point factor is the other factor points. The value has been divided by the number of points.

b) Reducing the total number of factors $\mathrm{S}$ with $\mathrm{W}$ (d) and factor $\mathrm{O}$ with $\mathrm{T}(\mathrm{e})$ : numbers $(\mathrm{d}=\mathrm{x})$ and $(\mathrm{e}=\mathrm{y})$ becoming the values or points on $\mathrm{X}$ and $\mathrm{Y}$ axes.

c) Investigating the position of the organization shown by the point $(\mathrm{x}, \mathrm{y})$ in the SWOT quadrant. 


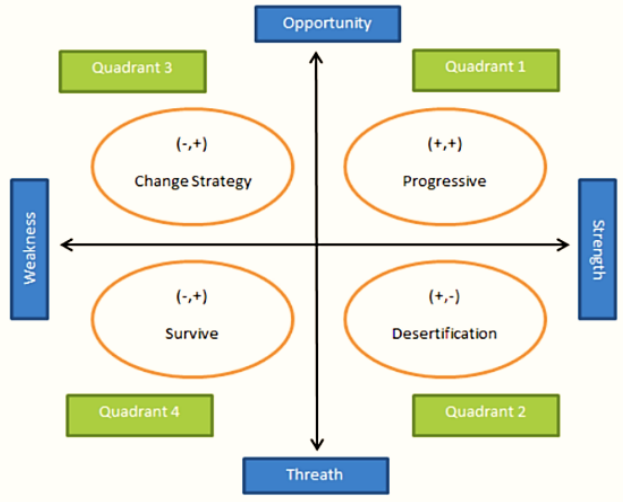

Fig. 1. Swot Matrix.

Quadrant I (positive, positive) This position signifies a potential and robust organization. The recommended strategy is progressive, indicating that the organization is in tip-top conditions and steady; hence, continuing to expand, enlarge growth and achieve maximum progress is possible.

Quadrant II (positive, negative) This position indicates a steady but challenging organization. The recommended strategy is diversification, meaning that the organization of the estimated wheel of the organization will have difficulty spinning only on the previous strategy. Therefore, the organization is advised to expand the range of tactical strategies immediately.

Quadrant III (negative, positive) This position demonstrates a weak but highly probable organization. The recommended strategy is changed, signifying that the organization is advised to replace the previous strategy. The reason is that old strategy might have difficulty capturing the existences while improving the performance of the organization.

Quadrant IV (negative, negative) This position signifies a weak organization and faces significant challenges. The recommended strategy is defensive, indicating that the organization's internal condition is in a dilemma. The organization is, therefore, advised to use defensive strategies to control internal performance and avoid further mudslides. This strategy is maintained while continuing to work on itself.

\section{RESUlt \& DisCussions}

\section{A. IFAS Analysis}

1) Financial

\begin{tabular}{lcc}
\multicolumn{3}{c}{ TABLE I: JAMKRINDO FINANCIAL RATIOS FROM $2016-2017$} \\
\hline Ratios & $\mathbf{2 0 1 7}$ & $\mathbf{2 0 1 6}$ \\
\hline Liquidity Ratio & & \\
Cash Ratio & $313.74 \%$ & $370.42 \%$ \\
Current Ratio & $769.09 \%$ & $712.07 \%$ \\
Solvability Ratio & & \\
Debt to Total Asset Ratio & $24.21 \%$ & $23.19 \%$ \\
Debt to Equity Ratio & $31.95 \%$ & $30.18 \%$ \\
Profitability Ratio & & \\
Gross Profit Margin & $28.85 \%$ & $29.75 \%$ \\
Return on Assets & $7.29 \%$ & $7.52 \%$ \\
Return on Equity & $7.49 \%$ & $6.72 \%$ \\
Activity Ratio & & \\
Assets Turnover & $17.14 \%$ & $17.37 \%$ \\
\hline
\end{tabular}

Based on this value (Table I), the company's ability to guarantee its current debt is still relatively good. Referring to PMK No. 99 / PMK. 010/2011 the guarantor's liquidity ratio has set up at least $150 \%$. The calculation of the total debt to equity ratio implies that each owner's capital has to bear $24,21 \%$ of the company's debt liability. The decline in GPM was $0.9 \%$ due to an increase in claim expenses in 2017 amounting to Rp1,004,610,000,000. Even so, there was an increase in guaranteed income, amounted to $\mathrm{Rp} 1,805,686,000,000$. This income will affect the gross profit margin. The ROA obtained at $7.29 \%$ is still above the industry average (time series)> 5\% where financial performance is said to be excellent and efficient.

2) Marketing

Perum Jamkrindo currently has nine Regional Offices, 56 Branch Offices and 16 Service Unit Offices by marketing 18 product groups which can make it easier for people to reach products issued by the company. We can see an excellent service reputation to customers by providing secure processing of guarantees and claims and constructing a unique relationship with customers.

3) Fostering \& ranking of MSMEs

At present, Perum Jamkrindo already has a particular unit that serves as an MSME rating. This activity has begun by working with universities and associations/ communities Until 2017, the number of MSMEs that were successfully ranked reached 4,288 MSMEs and the amount that had been fostered reached 1,424 MSMEs.

\section{4) Operation}

In administrative business processes (both branch and central offices) there are often information/data gaps. IT network infrastructure in some regions is still constrained by connectivity. Most of the indirect guarantee process services (through the bank), are already online. However, the direct guarantee submission process is still manual, suitable for suretyship products.

\section{5) Human resources}

HR productivity has decreased from 2014-2018 (Table II). It means the condition where the increase in the number of $\mathrm{HR}$ is not directly proportional to the rise in profits generated. The company need to improve HR quality so that HR productivity increases directly equivalent to the increase in HR.

TABLE II: HUMAN RESOURCES PRODUCTIVITY FROM 2014 - 2018 (IN MILLION RUPIAH)

\begin{tabular}{lccccl}
\hline \hline & 2014 & 2015 & 2016 & 2017 & 2018 \\
\hline $\begin{array}{l}\text { Number of } \\
\text { Employee }\end{array}$ & 501 & 611 & 901 & 1044 & 1002 \\
$\begin{array}{l}\text { Earning } \\
\text { After Tax }\end{array}$ & 664.038 & 625.354 & 692.045 & 801.846 & $\begin{array}{l}397.54 \\
3\end{array}$ \\
$\begin{array}{l}\text { Employee } \\
\text { Productivity }\end{array}$ & 1.325 & 1.023 & 768 & 768 & 397 \\
\hline \hline
\end{tabular}

Source: Annual Report Perum Jamkrindo 2014-2018

\section{B. IFAS Matrix}

After obtaining Strengths and Weaknesses in the Internal Environment Analysis, then through the IFAS Matrix weighting and rating will be carried out to achieve the following IFAS total score (Table III). 
TABLE III: PERUM JAMKRINDO IFAS MATRIX

\begin{tabular}{|c|c|c|c|c|c|}
\hline \multicolumn{3}{|r|}{ Internal Factors } & \multirow{2}{*}{$\begin{array}{c}\text { Weight } \\
0.14 \\
\end{array}$} & \multirow{2}{*}{$\begin{array}{c}\text { Rating } \\
4 \\
\end{array}$} & \multirow{2}{*}{$\begin{array}{c}\begin{array}{c}\text { Weight } \mathbf{x} \\
\text { Rating }\end{array} \\
0.560 \\
\end{array}$} \\
\hline \multirow{6}{*}{ 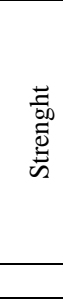 } & 1 & Guaranteed capacity is still large. & & & \\
\hline & 2 & $\begin{array}{l}\text { The ability of Perum Jamkrindo to pay off short-term } \\
\text { liabilities is relatively good. }\end{array}$ & 0.15 & 4 & 0.600 \\
\hline & 3 & Brand image as SOE. & 0.13 & 3 & 0.390 \\
\hline & 4 & $\begin{array}{l}\text { The quality of the guarantee and claim service process has } \\
\text { been relatively fast and good. }\end{array}$ & 0.043 & 3 & 0.129 \\
\hline & 5 & $\begin{array}{l}\text { Total Regional Offices (9), Branch Offices (56) and } \\
\text { Service Unit Offices (16). }\end{array}$ & 0.052 & 3 & 0.156 \\
\hline & 6 & Has a MSME Rating Unit. & 0.068 & 4 & 0.272 \\
\hline \multirow{6}{*}{ 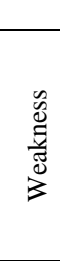 } & & Total Strength & & & 2.107 \\
\hline & 7 & Unable to increase microcredit guarantee rates. & 0.057 & 1 & 0.057 \\
\hline & 8 & $\begin{array}{l}\text { Business processes have not been integrated, efficient and } \\
\text { have not been able to utilize IT optimally. }\end{array}$ & 0.133 & 2 & 0.266 \\
\hline & 9 & Network management needs to be improved. & 0.088 & 2 & 0.176 \\
\hline & 10 & HR productivity is decreasing. & 0.092 & 2 & 0.184 \\
\hline & 11 & HR competency still needs to be improved. & 0.047 & 1 & 0.047 \\
\hline \multirow{2}{*}{\multicolumn{3}{|c|}{ Total Weakness }} & & & 0.730 \\
\hline & & & 1 & & 2.837 \\
\hline
\end{tabular}

The score assessment of the IFAS Matrix is 2.837. It implies that Jamkrindo has the innate ability to win aboveaverage opportunities.

\section{EFAS Analysis}

\section{1) Economy}

The growth of bank lending, especially MSME loans, Bank Indonesia (BI) noted that the growth of nonperforming loans (NPLs) in bank loans increased from 2014 to August 2018. The increase in NPLs showed an increase in the number of non-performing credits resulting in increased guarantee claims. This situation is a threat to Perum Jamkrindo because it can erode profits.

Claim expense at the end of 2017 amounted to Rp1,005 billion, an increase of $15 \%$ or Rp133 billion compared to 2016, which was Rp.872 billion. The increase is due to the rise in the volume of guarantees and also the surge in credit NPLs in 2017 so that the potential claims are higher. It is undoubtedly a threat to the guarantee industry because it can erode profits and especially for KUR products in helping access to MSME capital.

TABLE IV: MARKET SHARE OF KUR GUARANTEE PRODUCTS PERUM JAMKRINDO (IN TRILLION RUPiAH)

\begin{tabular}{llllll}
\hline \hline \multirow{2}{*}{$\begin{array}{c}\text { Bank } \\
\text { Distributor }\end{array}$} & \multicolumn{3}{c}{ Realization } & \multicolumn{2}{c}{ Percentage (\%) } \\
\cline { 2 - 6 } & Bank & Jamkrindo & Competitor & Jamkrindo & Competitor \\
\hline BRI & 69,47 & 37,35 & 32,12 & $54 \%$ & $46 \%$ \\
\hline BNI & 9,76 & 3,22 & 6,63 & $33 \%$ & $67 \%$ \\
\hline Mandiri & 13,34 & 8,43 & 4,91 & $63 \%$ & $37 \%$ \\
\hline TOTAL & 92,56 & 49,00 & 43,66 & - & - \\
\hline \hline
\end{tabular}

Based on Table IV it concludes that the company market share for KUR is $54 \%$, while the competitor such as BRI is only $46 \%$. However, the portion of company market share towards BNI is $33 \%$ lower than its competitors $(67 \%)$. Also, Jamkrindo is outperforming Bank Mandiri with a $63 \%$ market share. It means the company biggest competitor is Bank BNI. Bank as the primary influencer for the purchase of KUR guarantee products does not have switching costs to switch from one guarantee to another.

2) Legal

Referring to PP No. 35 of 2018, the Jamkrindo Corporation is legally to open the market other than MSMEs in the context of SOE Synergy. As one of the SOEs, Jamkrindo currently has good cooperative relations with various SOEs. This relation is an opportunity for companies to expand their markets.

3) Industry

Until 2018, there are 23 guarantee companies in Indonesia consisting of 2 sharia private guarantee companies, 2 well-known private guarantee companies, 18 regional guarantee companies and one government guarantee company, Perum Jamkrindo. The emergence of local guarantee companies or Regional Credit Guarantees
(Jamkrida) is expected to be able to improve the financial literacy of MSMEs in the regions, especially in terms of ease of access to credit.

\section{4) Political}

Relevant factors and should be observed by Perum Jamkrindo, namely ahead of the 2019 Presidential Election. Perum Jamkrindo has a guaranteed product that is a government assignment program, namely, Microcredit Program (KUR). Thus, the sustainability of this product intensely depends on government policy. Nevertheless, it is believed that whoever the elected President in 2019, will carry out pro-people programs. The potential related to the change in the KUR program policy will still exist and needs to be anticipated by the KUR program guarantor.

\section{5) Technology}

The role of information technology is needed to increase efficiency, assist transactions, improve financial inclusion, and support supervision. The Ministry of Communication and Information (Kominfo) targets that by 2020 Micro, Small and Medium Enterprises (MSMEs) products can compete with foreign products and dominate the Ecommerce market as support from the government for the advancement of information technology in Indonesia. 
6) Social

The current development of MSMEs is often carried out by the central government and regional governments through related institutions. This development aims to form new entrepreneurs in Indonesia. Relevant institutions that often hold coaching are the Office of Cooperatives, Micro Enterprises, and Labor, BUMN, and Universities.

\section{EFAS Matrix}

The EFAS Matrix was carried out by weighing and rating each of the external factors. The results of the calculation of weights and ratings are obtained from the research conducted by the author based on the above data and adjustments from the Strategic Planning Division (Table V).

TABLE V: EFAS MATRIX OF PERUM JAMKRINDO

\begin{tabular}{|c|c|c|c|c|c|}
\hline \multicolumn{3}{|r|}{ External Factors } & \multirow{2}{*}{$\begin{array}{c}\text { Weight } \\
0.141\end{array}$} & \multirow{2}{*}{$\begin{array}{c}\text { Rating } \\
3\end{array}$} & \multirow{2}{*}{$\begin{array}{c}\text { Weight x Rating } \\
0.423\end{array}$} \\
\hline \multirow{5}{*}{ 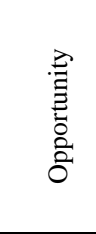 } & 1 & There is considerable market potential in various economic sectors. & & & \\
\hline & 2 & Market expansion and efficiency through BUMN synergy & 0.110 & 4 & 0.440 \\
\hline & 3 & $\begin{array}{l}\text { Co-guarantee collaboration between a large capacity guarantee } \\
\text { institution and a regional guarantee institution. }\end{array}$ & 0.103 & 4 & 0.412 \\
\hline & 4 & Utilization of IT for back-end, front-end processes. & 0.128 & 2 & 0.256 \\
\hline & 5 & There is a need to develop MSMEs in marketing skills and management. & 0.085 & 3 & 0.255 \\
\hline \multirow{5}{*}{ 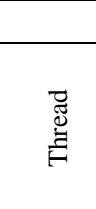 } & & Total Opportunity & & & 1.786 \\
\hline & 6 & The potential claim guarantee rate increased due to the increase in NPL. & 0.098 & 4 & 0.392 \\
\hline & 7 & High level of competition in the guarantee industry. & 0.135 & 3 & 0.405 \\
\hline & 8 & Uncertainty in the stability of microcredit program policies. & 0.070 & 3 & 0.210 \\
\hline & 9 & Banking bargaining power is high in the guarantee industry. & 0.130 & 1 & 0.130 \\
\hline \multicolumn{3}{|r|}{ Total Thread } & & & 1.137 \\
\hline TOTAL & & & 1.000 & & 2.923 \\
\hline
\end{tabular}

The results of the Strengths, Weaknesses, Opportunities and Threats are weighted and rated with the IFAS and EFAS Matrix. So that EFAS value is 2,923, means that the ability of the company to capture opportunities and overcome external threats is above average. The IFAS value is 2,851 , implying that the company has the ability to response the opportunities is above the average.

\section{E. SWOT Analysis}

To create the SWOT quadrant matrix, we use the calculation of IFAS Matrix and previous EFAS Matrix. However, to find the coordinates, every aspect in IFAS (Strengths) and EFAS (Opportunities) will be compared, and the difference sought. As can be seen in Table VI, the coordinate point is obtained at $(1.377 ; 0.649)$. Alternative strategies are also obtained, namely SO Strategy, WO Strategy, ST Strategy and WT Strategy.

TABLE VI: SWOT MATRIX MATRIX CALCULATION RESULTS

\begin{tabular}{llll}
\hline \hline Internal Factors & Scores & External Factors & Scores \\
\hline Strength & 2.107 & Opportunity & 1.786 \\
\hline Weakness & 0.730 & Thread & 1.137 \\
\hline Difference & 1.377 & Difference & 0.649 \\
\hline \hline
\end{tabular}

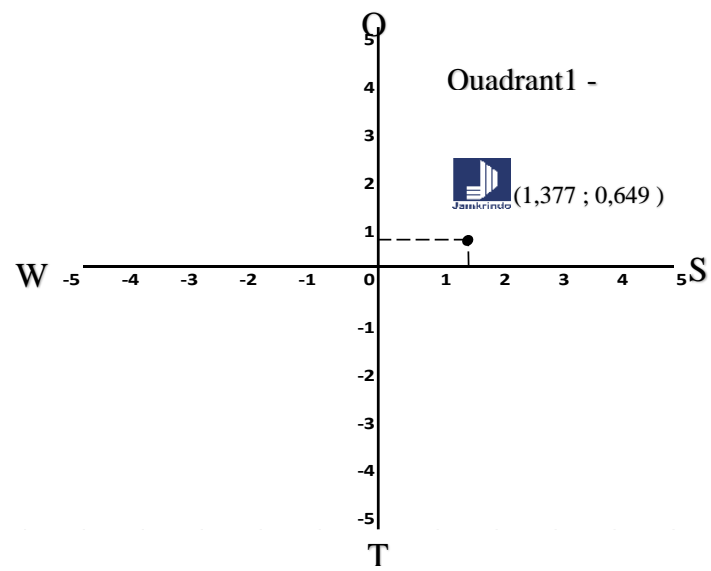

Fig. 2. Position of Perum Jamkrindo with SWOT matrix diagram.
Based on the above calculation, it describes that the position of the Perum Jamkrindo is in the Progressive Quadrant I of the SWOT Matrix, as shown in Fig. 2.

TABLE VII: JAMKRINDO SWOT MATRIX ANALYSIS

\begin{tabular}{|c|c|c|}
\hline & Strengths $(S)$ & Weakness (W) \\
\hline 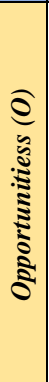 & $\begin{array}{l}\text { S-O Strategies } \\
\text { 1. Market penetration to } \\
\text { potential sectors by utilizing } \\
\text { BUMN synergies (S1, S2, } \\
\text { O1, O2, O3) } \\
\text { 2. More comprehensive } \\
\text { MSME ranking and } \\
\text { coaching (S4, S5, O5) } \\
\text { 3. IT-based service } \\
\text { development (S2, S3, O4) } \\
\text { 4. Co-guarantee with } \\
\text { Jamkrinda (S2, S4, O2, O3) }\end{array}$ & $\begin{array}{l}\text { W-O Strategies } \\
\text { 1. Improved IT systems to } \\
\text { support back-end and } \\
\text { front-end processes (W1, } \\
\text { W2, O4) } \\
\text { 2. Strengthening } \\
\text { competencies } \\
\text { managing SOE synergies } \\
\text { to increase } \\
\text { productivity (W3, W4, } \\
\text { O2) }\end{array}$ \\
\hline 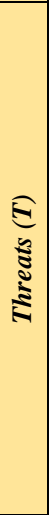 & $\begin{array}{l}\text { S-T Strategies } \\
\text { 1. Co-guarantee with other } \\
\text { industries, including } \\
\text { insurance companies (S1, } \\
\text { T2) } \\
\text { 2. Increasing non-program } \\
\text { guarantees (S1, S2, S3, S4, } \\
\text { T3) } \\
\text { 3. Increasing the role of } \\
\text { regions and branches to } \\
\text { foster good relations and } \\
\text { bring banking needs to } \\
\text { guarantees (S4, T2, T4) } \\
\text { 4. To rank and guide MSMEs } \\
\text { to help prepare for banking } \\
\text { access (S4, S5, T2, T4) }\end{array}$ & $\begin{array}{l}\text { W-T Strategies } \\
\text { 1. Increasing HR } \\
\text { competency in the analysis } \\
\text { of credit guarantee risk so } \\
\text { that the selection is } \\
\text { guaranteed to be more } \\
\text { selective (W4, T1) } \\
\text { 2. Management of networks } \\
\text { in maintaining good } \\
\text { relations with banks, other } \\
\text { BUMNs, and business } \\
\text { people (W2, T2) }\end{array}$ \\
\hline
\end{tabular}

The outcome of business strategy using SWOT Analysis approach is progressive with the focus on the SO (Strengthopportunity) strategy (Table VII). The strategy can be done by doing market penetration to potential sectors by utilizing the synergy of BUMN, ranking and fostering more comprehensive MSMEs. Moreover, developing IT-based services and co-guarantee with Jamkrida are also crucial to expand business scope.

The findings are in line with Irawati (2017) [19], who 
used a SWOT analysis to identify the company's internal and external factors. Analysis of internal and external factors is used to determine the company's performance. However, the Previous Scientific Work only identified internal and external factors of the company. Irpah Rambe (2018) and Dita Amanah and Fauzia Agustini (2016) in their writing, also have similarities in theory and results [20], [21].

\section{CONCLUSION}

As a result, the position of Perum Jamkrindo is in Progressive Quadrant I with a total strength-weakness of 1,377 and total threats of 0.649 . This SWOT analysis also produces an alternative focus of the strategy, namely on the SO Strategy. The business strategy that can be taken when viewed from the SWOT Analysis is to hold or maintain a product innovation strategy aimed at market development, marketing with potential regional and branch mapping, improving service quality to partners, and integrating IT systems for the effectiveness of the business.

\section{CONFLICT OF INTEREST}

The authors declare no conflict of interest.

\section{AUTHOR CONTRIBUTIONS}

Authors of this journal consist of 3 people. Vindaniar Putri as the first author, conceived of the presented idea. While, Dhea S. Tasya and Ajeng Rahayu as the second writer developed the theory as baseline study to construct the methodology of this study. The computation was performed by Dhea S. Tasya, then the first author verified the analytic method. Vindaniar Putri also encouraged Ajeng Rahayu to investigate the internal and external factors to complete the EFAS and IFAS matrix of the company. All authors discussed the results and contributed to the final manuscript.

\section{ACKNOWLEDGMENT}

Authors would like to thank Perum Jamkrindo as our partner in writing this journal. We are very grateful for their support and their brilliant ideas to complete this journal.

\section{REFERENCES}

[1] A. A. Thompson and A. J. Strickland, Strategic Management: Concepts and Cases, 13th ed. USA: McGraw-Hill/Irwin, 2003.

[2] L. W. Liang, B. Y. Huang, C. F. Liao, and Y. T. Gao, "The impact of SMEs' lending and credit guarantee on bank efficiency in South Korea," Rev. Dev. Financ., vol. 7, no. 2, pp. 134-141, 2017.

[3] Apriyani. (2015). Menengok Industri Penjaminan Di Luar Negeri. [Online]. Available: http://infobanknews.com/menengok-industripenjaminan-di-luar-negeri/

[4] N. Yoshino and F. Taghizadeh-Hesary, "Optimal credit guarantee ratio for small and medium-sized enterprises' financing: Evidence from Asia," Econ. Anal. Policy, vol. 62, pp. 342-356, 2019.

[5] N. Rahayu, "Perluas akses modal UMKM, pemerintah kembali turunkan suku bunga KUR,” Warta Ekonomi, Jakarta, July 2019.

[6] T. Hill and R. Westbrook, "SWOT analysis: It's time for a product recall," Long Range Plann, 1997.
[7] Y. Yang, "SWOT-TOPSIS integration method for strategic decision," in Proc. the International Conference on E-Business and EGovernment, 2010.

[8] B. Phadermrod, R. M. Crowder, and G. B. Wills, "Importanceperformance analysis based SWOT analysis," Int. J. Inf. Manage., 2019.

[9] H. Weihrich, H. Koontz, and M. V. Cannice, Management : A Global and Entrepreneurial Perspective, 12th ed. New Delhi: Tata McGrawHill, 2008.

[10] G. Liu, S. Zheng, P. Xu, and T. Zhuang, "An ANP-SWOT approach for ESCOs industry strategies in Chinese building sectors," Renewable and Sustainable Energy Reviews, 2018.

[11] J. D. Hunger and T. L. Wheelen, Essentials of Strategic Management, 5th ed. New Jersey: Prentice Hall, 2003.

[12] H. Jogiyanto, Analisa dan Desain Sistem Informasi: Pendekatan Terstruktur Teori dan Praktik Aplikasi Bisnis, 1st ed. Yogyakarta: Andi, 2005

[13] F. R. David, Manajemen Strategis, 10th ed. Jakarta: Salemba Empat, 2006.

[14] Z. Nisak, "Analisis Swot untuk menentukan strategi kompetitif," $J$. Ekbis, 2004.

[15] F. Rangkuti, Teknik Membedah Kasus Bisnis Analisis SWOT Cara Perhitungan Bobot, Rating, dan OCAI, 2013.

[16] F. R. David, Strategic Management Concepts and Cases, 13th ed. 2011

[17] E. P. Lestari, Pemasaran Strategik: Bagaimana Meraih Keunggulan Kompetitif, 1st ed. Yogyakarta: Graha Ilmu, 2011.

[18] Rivani, S. J. Raharja, and R. Arifianti, "SWOT analysis on the export-oriented ceramic industry centre in Purwakarta, Indonesia," Rev. Integr. Bus. Econ. Res., vol. 7, no. 2, pp. 189-199, 2018.

[19] A. Irawati and A. Marlina, "Strategi pemasaran kur pada Pt.Bank Rakyat Indonesia TBK. Cabang Bogor Pajajaran," J. Keuang. dan Perbank., 2017.

[20] I. Rambe, "Analisis strategi pengembangan usaha pembuatan tahu pada pengrajin tahu bandung kecamatan padang hulu tebing tinggi," Universitas Islam Negeri Sumatera Utara, 2018.

[21] D. Amanah and F. Agustini, "Strategi pengembangan produk taman margasatwa medan, Indonesia," in Proc. Prosiding Seminar Nasional Ekonomi dan Bisnis \& Call For Paper FEB UMSIDA 2016, 2016, pp. $130-142$.

Copyright $(\odot 2020$ by the authors. This is an open access article distributed under the Creative Commons Attribution License which permits unrestricted use, distribution, and reproduction in any medium, provided the original work is properly cited (CC BY 4.0).

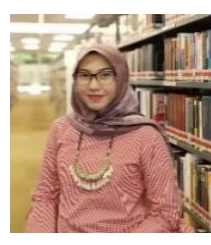

Vindaniar Y. Putri is an assistant professor of Universitas Indonesia, reached her graduate degree from magister of management, Faculty of Economic \& Business, Universitas Indonesia majoring in financial management. She has been actively being a lecturer since 2016. Her research papers are mostly about portfolio management, investment, and stockbond return.

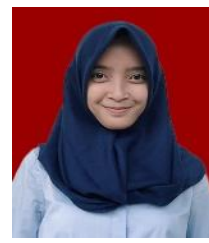

Dhea Shaumi Tasya is a diploma holder from Indonesia University. She finished her diploma degree from Administrative Financial \& Banking Study Program. She's currently working as an intern at Perum Jamkrindo for 6 months. Her interest of study mainly in credit guarantee and microcredit program.

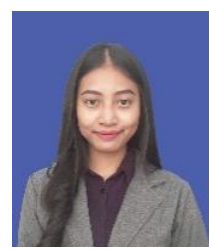

Ajeng Rahayu is a diploma holder from Financial \& Banking Administration Department, Universitas Indonesia. She finished her six months' internship program at Perum Jamkrindo and now has been actively working at financial industry in Indonesia. Her interest of study mostly in business strategy. 